\title{
Quality Control of Margarine Production by Applying Six Sigma Method in PT. XYZ
}

\author{
Beatrix Oscar, Billy Marten, Jenifer, Mochamad Sandy Triady
}

\begin{abstract}
This research took place in PT. XYZ, Jakarta. The purposes of this research are to know which sigma company has reached this level, the factors that can cause defective products and the best solutions to reduce the number of faulty products. This research is using qualitative methods to collect data. A data analysis method used in this research is Six Sigma DMAIC (Define-Measure-Analyze-Improve-Control). The result from this research showed that the company's sigma level is in 3.53 for $\mathbf{m c}$ margarine and 3.52 for $G B$ margarine, the main factor that causes the defective product in PT. XYZ is a misstep when adding the ingredients and the emulsifiers, which is caused by the workers (man). Recommended actions that were given by the researcher $s$ are the implementation of the $5 S$ system and Signboard Strategy, the which is making an indication or an explanation about the place, name of supporting materials, and the amount of supporting documents adding in the making of margarine production.
\end{abstract}

Keywords: Defective Product, Quality, Six Sigma, DMAIC.

\section{INTRODUCTION}

In this modern era, competition in the business industry is increasingly widespread, and this causes the company to develop strategies and broader thinking patterns to compete with other companies. The palm oil industry is an example of an industry whose development can't predict over time. Palm oil itself can be processed into various types of food; the most common example of production is margarine, which is consumed almost daily by people in Indonesia. PT. XYZ, which is a company that produces fat and oil consumption, is made the primary basis of oil palm be in such Margarine, Shortening, and some products derived from palm oil. PT. XYZ has been established since 1990, and currently continues to expand its business. The development of PT. XYZ is quite fast, which is marked by its products that have entered national and international markets such as Asia, the Middle East to other Asia Pacific countries. But there are production constraints experienced by PT. XYZ, namely production

Revised Manuscript Received on July 10, 2020.

* Correspondence Author

Beatrix Oscar, Management Department, BINUS Business School Undergraduate Program, Bina Nusantara University, Jakarta, Indonesia.

Billy Marten, Management Department, BINUS Business School Undergraduate Program, Bina Nusantara University, Jakarta, Indonesia.

Jenifer, Management Department, BINUS Business School Undergraduate Program, Bina Nusantara University, Jakarta, Indonesia.

Mochamad Sandy Triady*, Management Department, BINUS Business School Undergraduate Program, Bina Nusantara University, Jakarta, Indonesia. E-mail: sandy.triady@binus.ac.id

(C) The Authors. Published by Blue Eyes Intelligence Engineering and Sciences Publication (BEIESP). This is an open access article under the CC BY-NC-ND license (http://creativecommons.org/licenses/by-nc-nd/4.0/) defects in Margarine MC and Margarine GB. The results of the survey from the beginning of the study found that the amount of margarine production and defective products at PT. XYZ is as listed in the following table.

Table- I: Total of Production Margarine MC and Margarine GB Period July 2015 - December 2017

\begin{tabular}{|c|c|c|c|c|c|}
\hline \multirow{2}{*}{ Period } & \multicolumn{2}{|c|}{ Margarine MC (200gr) } & \multicolumn{3}{|c|}{ Margarine GB (200gr) } \\
\cline { 2 - 6 } & $\begin{array}{c}\text { Production } \\
\text { (pcs) }\end{array}$ & Defect (PCS) & $\begin{array}{c}\text { Production } \\
\text { (pcs) }\end{array}$ & Defect (PCS) & $\%$ \\
\hline 15-Jul & 10349 & 996 & 9725 & 798 & 8.21 \\
\hline 15-Aug & 8913 & 785 & 9358 & 864 & 9.23 \\
\hline 15-Sep & 9828 & 924 & 8932 & 841 & 9.42 \\
\hline 15-Oct & 10935 & 969 & 10251 & 897 & 8.75 \\
\hline 15-Nov & 11273 & 927 & 9316 & 842 & 9.04 \\
\hline Dec. 15 & 12361 & 1036 & 9814 & 906 & 9.23 \\
\hline 16-Jan & 11916 & 1108 & 10625 & 1002 & 9.43 \\
\hline 16-Feb & 9842 & 701 & 6995 & 589 & 8.42 \\
\hline 16-Mar & 16779 & 1329 & 9819 & 898 & 9.15 \\
\hline 16-Apr & 15639 & 1527 & 8925 & 786 & 8.81 \\
\hline 16-May & 13842 & 1302 & 9204 & 682 & 7.41 \\
\hline Jun. 16 & 9421 & 625 & 9840 & 592 & 6.02 \\
\hline 16-Jul & 8621 & 598 & 9903 & 501 & 5.06 \\
\hline 16-Aug & 9439 & 510 & 10076 & 547 & 5.43 \\
\hline 16-Sep & 10519 & 657 & 10335 & 551 & 5,33 \\
\hline 16-Oct & 11476 & 683 & 9920 & 570 & 5.75 \\
\hline 16-Nov & 12517 & 618 & 10086 & 524 & 5,20 \\
\hline Dec. 16 & 13581 & 690 & 10276 & 571 & 5.56 \\
\hline 17-Jan & 13056 & 761 & 9938 & 598 & 6.02 \\
\hline 17-Feb & 13413 & 756 & 10073 & 497 & 4.93 \\
\hline 17-Mar & 11518 & 749 & 9906 & 510 & 5.15 \\
\hline 17-Apr & 13573 & 628 & 10148 & 562 & 5.54 \\
\hline 17-May & 13076 & 674 & 9524 & 551 & 5.79 \\
\hline 17-Jun & 11601 & 751 & 9583 & 504 & 5.26 \\
\hline 17-Jul & 12109 & 642 & 9352 & 582 & 6.22 \\
\hline 17-Aug & 13812 & 768 & 7294 & 551 & 7.55 \\
\hline 17-Sep & 11852 & 612 & 7502 & 534 & 7.12 \\
\hline 17-Oct & 12230 & 781 & 7712 & 534 & 6.92 \\
\hline 17-Nov & 14107 & 749 & 7915 & 589 & 7.44 \\
\hline 17-Dec & 13760 & 728 & 7052 & 534 & 7.57 \\
\hline To tal & 361358 & 24584 & 279399 & 19507 & \\
\hline
\end{tabular}

Source: PT. XYZ (2018)

Published By:

Blue Eyes Intelligence Engineering \& Sciences Publication

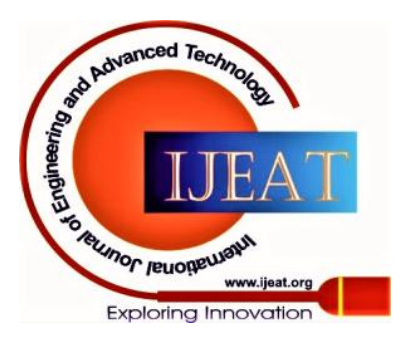


Based on the table above, the highest level of disability is $9.62 \%$, and the lowest level of disability is $4.63 \%$ in Margarine MC. While for Margarine GB, the highest level of disability was $9.43 \%$, and the lowest level of disability was 5.06\%. measure of the performance of a production system that enables companies to improve product quality based on research conducted by Saprullah (2017) entitled "Analysis of Product Quality Control Using Six Sigma Methods at King Roti in Samarinda." The Six Sigma method is integral in improving quality. This method is proven effective to enhance and improve the quality of products and production processes, so that the number of defective products that harm the company can be minimized, and expected profits from the company will increase based on the results of research conducted by [1] entitled "Quality Control of Green Tea Products Using a Six Sigma Approach". Based on the above problems, we want to research to find out the sigma level (level of production quality) that has been achieved by PT. in the production process of margarine $\mathrm{MC}$ and margarine $\mathrm{GB}$ and solutions to overcome these problems with the title of the study "Analysis of Quality Control of Margarine Production by Implementing Six Sigma Method in PT.XYZ".

\section{RESEARCH METHOD}

The research method used by researchers is Six Sigma by using DMAIC analysis (Define, Measure, Analyze, Improve, and Control), which can be used to determine the cause of the problem of high production defects from PT. XYZ.

\section{A. Define}

\section{SIPOC diagram}

In this first stage, the researchers made a diagram SIPOC which aims to analyze the entire supplier (suppliers involved in the production process), Input (all that enter into the production process), Process (a process which will be upgraded), Output (overall output from the production process), and the Customer (the person who will receive the output).

2. Critical to Quality (CTQ)

The researcher will determine some fax tor essential to be known by the company using tables Critical to Quality (CTQ).

\section{B. Measure}

\section{Control Chart}

This stage, the researcher make a Control Chart that is used to monitor the stability of a process and study the process changes in the future.

2. Calculating Defect per Million Opportunities (DPMO)

The measurement is carried out to determine the level of product quality at PT. XYZ currently and the process of defective products that have been identified based on production data and incomplete product data of PT. XYZ.

\section{Analyze}

\section{Pareto Diagram}

Applied by counting the number of causes of disability that may occur from the existence of poor quality in a product or service, which is then carried out the development of the frequency distribution of existing data.
Previous research shows that Six Sigma can be used as a $\mathrm{XYZ}$ and to find out the factors that influence product defects

\section{Fishbone Diagram or Cause and Effect Diagram}

Used to determine the factors that influence product defects in PT. XYZ, by analyzing the causative factors and separating the root causes from each of the causative factors found.

3. FMEA (Failure Mode and Effect Analysis)

It is a systematic approach to identifying all the failures that might occur in a design, manufacturing process, or service process.

\section{Improve}

In the improve phase, researchers provide corrective action for problems that occur at PT. XYZ

\section{E. Control}

At the control stage, the results of quality improvement are documented and disseminated. Solutions that were successfully applied in improving the production process were made into the company's operational standards (SOP), as well as the ownership and responsibility of the process, and the Six Sigma method ended at this stage.

\section{RESULT AND DISCUSSION}

\section{A. Define}

At this stage, the researchers determine the flow of the production process and the types of product defects that occur in PT. XYZ As for the define stage, what the researcher will do are:

1. Make Diagram SIPOC

This SIPOC diagram aims to analyze all Suppliers (suppliers involved in the production process), Inputs (everything that enters the production process), Processes (processes that will be improved later), Outputs (overall outputs of the production process), and Customers (people who will receive the output).

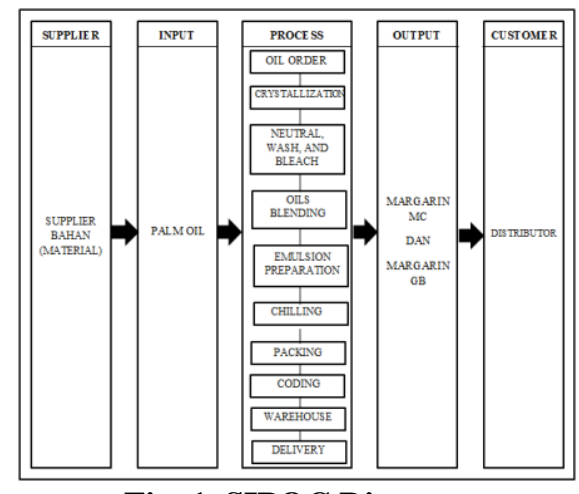

Fig. 1. SIPOC Diagram

Source: PT. XYZ (2018

\section{Critical to Quality (CTQ)}

After making the SIPOC diagram, the researcher will determine several important factors to be known by the company by using the Critical to Quality (CTQ) table which is used to determine the types of disabilities that affect the quality of Margarine MC and Margarine GB products, namely sandy margarine, oily margarine out), and pale margarine.

Published By:

Blue Eyes Intelligence Engineering

\& Sciences Publication

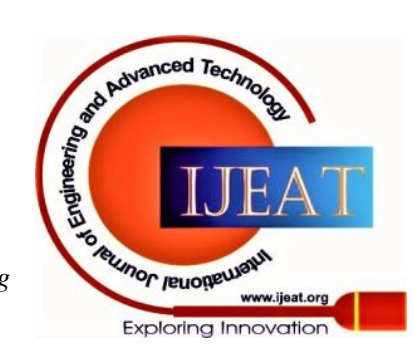


Table- II: Critical to Quality

\begin{tabular}{|l|l|l|}
\hline No & Type of Disability & Information \\
\hline 1 & Sandy Butter & $\begin{array}{l}\text { The texture of butter has } \\
\text { lumps and is not smooth. }\end{array}$ \\
\hline 2 & $\begin{array}{l}\text { Butter produces a } \\
\text { layer of oil }\end{array}$ & $\begin{array}{l}\text { There are two layers in } \\
\text { butter, the bottom layer of } \\
\text { butter is feasible in general, } \\
\text { and the upper layer has seen } \\
\text { a collection of oil as high as } \\
0.5 \text { cm }\end{array}$ \\
\hline 3 & Butter changes color & $\begin{array}{l}\text { The color of butter is } \\
\text { generally yellow but has } \\
\text { been deformed to white }\end{array}$ \\
\hline
\end{tabular}

Source: PT. XYZ (2018)

\section{B. Measure}

Researchers will measure the production process from July 2015 - December 2017. As for the measuring stage, what the researchers are doing is:

1. Control Chart

In this stage, the researcher makes a Control Chart that is used to monitor or monitor the stability of a process and study the process changes in the future.

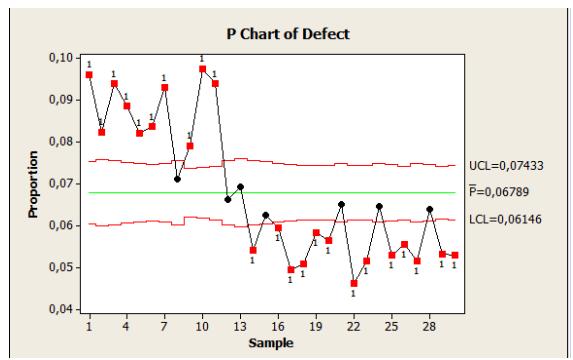

Fig. 2. P-Chart Margarine MC

Source: Minita b 17

Based on the graph above, it can be seen that there is no control limit on the production of Margarine MC for 23 months.

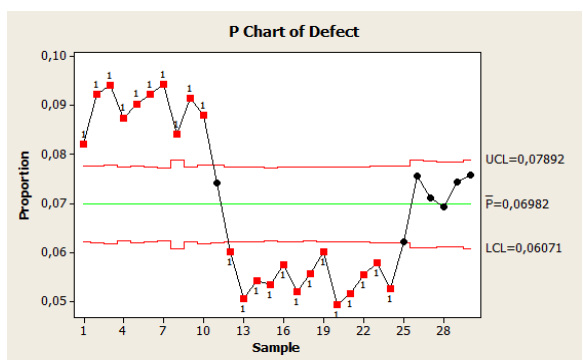

Fig. 3. P-Chart Margarine GB Source: Minitab 17

Likewise, in the GB Margarine production, based on the graph, it can be seen that there are only seven months of production that are within the control limits.

Calculating Defect per Million Opportunities (DPMO)\

The measurement is carried out to determine the level of product quality at PT. XYZ currently and the process of defective products that have been identified based on production data and incomplete product data of PT. XYZ. Based on available data, the DPMO calculation results are obtained using the help of a sigma calculator, which is 22,677 on Margarine MC with a sigma level of 3.5.

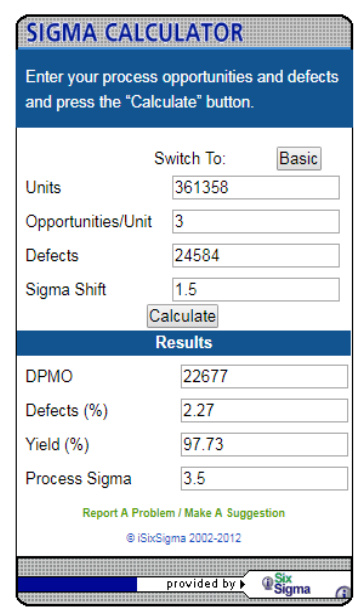

Fig. 4. Total DPMO Margarine MC

Source: www.isixsigma.com

In the DPMO calculation, Margarine GB is known to be 23,272 with a sigma level of 3.49 .

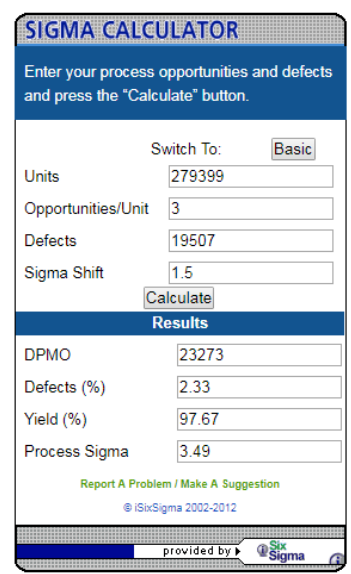

Fig..5 Total D of PMO Margarine GB

Source: www.isixsigma.com

\section{Analyze}

At this analyze stage, researchers used a Pareto diagram and a causal diagram aimed at analyzing and finding the main factors of disability of margarine $\mathrm{MC}$ and margarine $\mathrm{GB}$ products at PT. XYZ.

1. Pareto diagram

1.2 Cumulative Table of Margarine MC

\begin{tabular}{|c|c|c|c|c|c|}
\hline No. & Defect & $\begin{array}{c}\text { Total } \\
\text { Defect }\end{array}$ & $\begin{array}{c}\text { Percentage } \\
\text { of Defect (\%) }\end{array}$ & $\begin{array}{c}\text { Cumu } \\
\text { lative }\end{array}$ & $\begin{array}{c}\% \\
\text { Cumu } \\
\text { lative }\end{array}$ \\
\hline 1 & Sandy & 11870 & $48.29 \%$ & 11870 & $\begin{array}{c}48.29 \\
\%\end{array}$ \\
\hline 2 & Greasy & 6685 & $27.19 \%$ & 18555 & $\begin{array}{c}72.81 \\
\%\end{array}$ \\
\hline 3 & $\begin{array}{c}\text { Change } \\
\text { color }\end{array}$ & 6027 & $24.52 \%$ & 24582 & $100 \%$ \\
\hline $\begin{array}{c}\text { Tota } \\
1\end{array}$ & & 24582 & & & \\
\hline
\end{tabular}

Source: Data Processing Results (2018)

After calculating the cumulative percentage and also the increasing frequency, the above data will be processed and form a Pareto graph as follows:

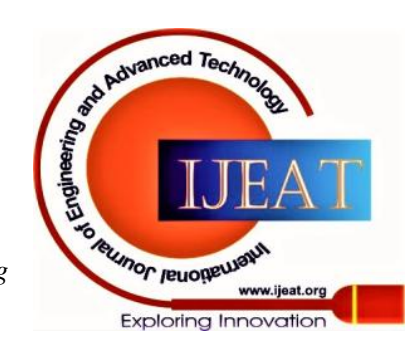




\section{Quality Control of Margarine Production by Applying Six Sigma Method in PT. XYZ}

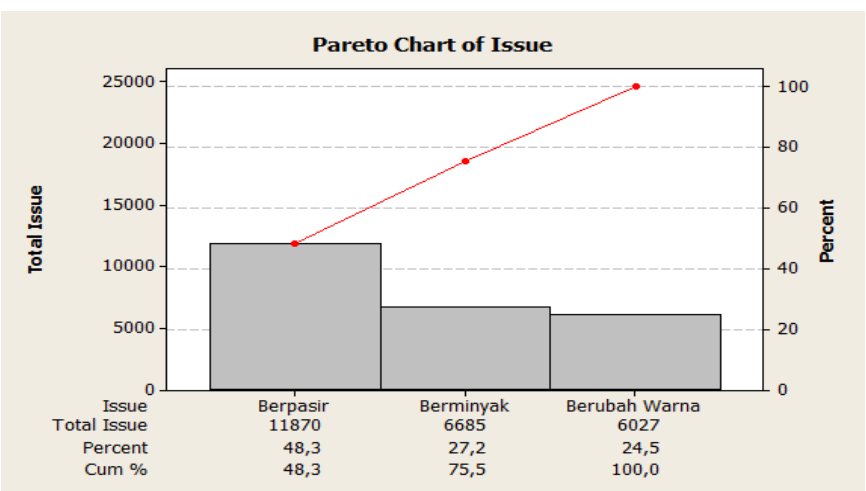

Fig. 6. Diagram of MC Areto Pareto Marg Source: Minitab 17

It can be seen in the table above that there are three types of disabilities in MC Margarine products, which are sandy, oily, and discolored. Where the nature of the sand defect is a type of product defect with the highest level of importance, with a percentage of $48.3 \%$, followed by oiliness of $27.2 \%$ and the lowest is changing color with a rate of $24.5 \%$.

Table- III: Cumulative Table for Margarine GB

\begin{tabular}{|c|c|c|c|c|c|}
\hline No. & $\begin{array}{c}\text { Defec } \\
\mathrm{t}\end{array}$ & $\begin{array}{c}\text { Total } \\
\text { Defe } \\
\text { ct }\end{array}$ & $\begin{array}{c}\text { Percentage } \\
\text { of Defect ( } \\
\%\end{array}$ & $\begin{array}{c}\text { Cumulati } \\
\text { ve }\end{array}$ & $\begin{array}{c}\% \\
\text { Cumu } \\
\text { lative }\end{array}$ \\
\hline 1 & Sandy & 9115 & $46.72 \%$ & 9115 & $\begin{array}{c}46.72 \\
\%\end{array}$ \\
\hline 2 & $\begin{array}{c}\text { Greas } \\
\text { y }\end{array}$ & 5269 & $27.01 \%$ & 14384 & $\begin{array}{c}73.73 \\
\%\end{array}$ \\
\hline 3 & $\begin{array}{c}\text { Chan } \\
\text { ge } \\
\text { color }\end{array}$ & 5123 & $26.26 \%$ & 19507 & $100 \%$ \\
\hline $\begin{array}{c}\text { Tot } \\
\text { al }\end{array}$ & & $\begin{array}{c}7950 \\
7\end{array}$ & & & \\
\hline
\end{tabular}

Source: Data Processing Results (2018)

After calculating the cumulative percentage and also the increasing frequency, the data above will be processed and form a Pareto graph, as follows:

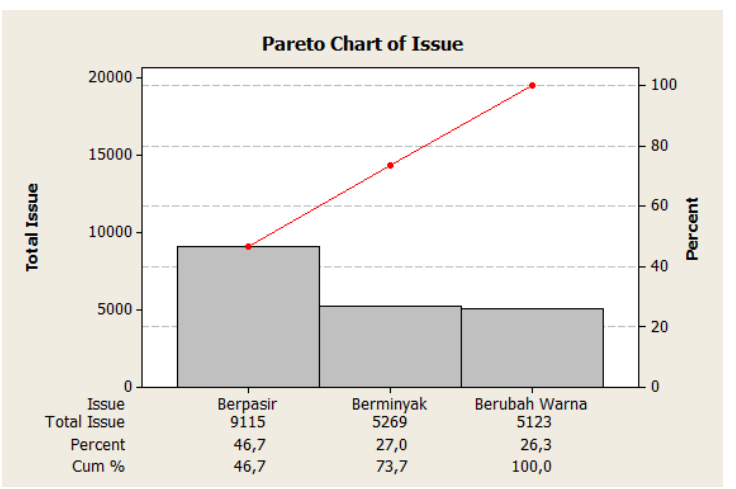

Fig. 7. GB Pareto Margarine Diagram Source: Minitab 17

Based on the diagram above, it can be seen that there are three types of product defects in Margarine GB, which are sandy, oily, and change color. Where the nature of the sand defect is a type of product defect with the highest level of importance with a percentage of $46.7 \%$, then followed by oily by $27 \%$ and the lowest is changing color with a rate of $26.3 \%$. After getting the results from the Pareto chart, researchers can determine what types of disabilities will be analyzed more deeply on the fishbone diagram, namely by looking at the most significant percentage of limitations.

\section{Cause and Effect Diagrams (Fishbone Diagrams)}

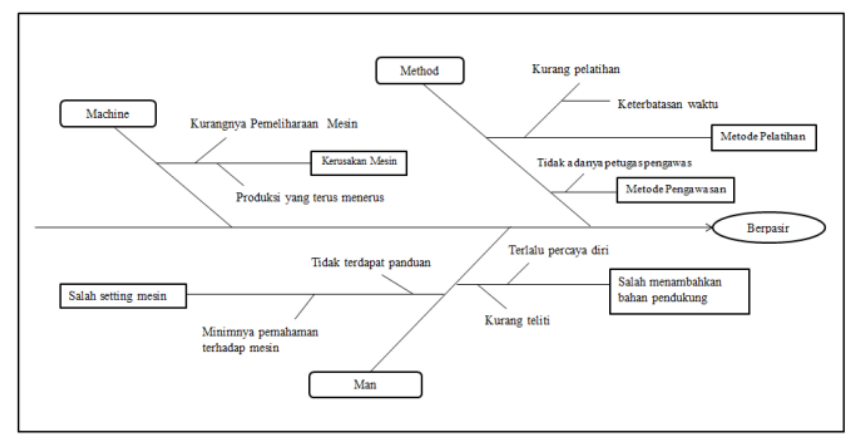

Fig. 8. Fishbone Diagram Sandy

Source: Data Processing Results (2018)

After conducting a Pareto analysis, it is known that the most significant percentage of disability occurs in the type of sandy margarine disability. Therefore, researchers conducted a study using the gram of cause and effect to look for the factors that cause the problem, and there are known to be three factors causing sandy margarine disability, namely Man, Machine, and Method.

The following is an explanation of the fishbone diagram in the sandy margarine defect based on Figure 1.8:

1. Machine

To produce margarine, PT. XYZ relies on the machine for its production process, but the machine sometimes breaks down while the production process is in progress.

2. Humans

Defects occur due to the negligence of workers in operating machinery and lack of accuracy in working.

3. Method

PT. XYZ applies the training to its workers only when workers begin to join. Product defects produced by PT. XYZ is caused by inappropriate methods, including less optimal supervision during the production process due to the absence of permanent supervisors during production.

3. Failure Mode and Effect Analysis (FMEA)

From the causal diagram that may be made FMEA at PT. XYZ with a scale and calculation of the value of the RPN (Risk Priority Number) to identify the cause of the problem, assessing all risks arising from the production process.

Table- IV: Failure Mode and Effect Analysis (FMEA)

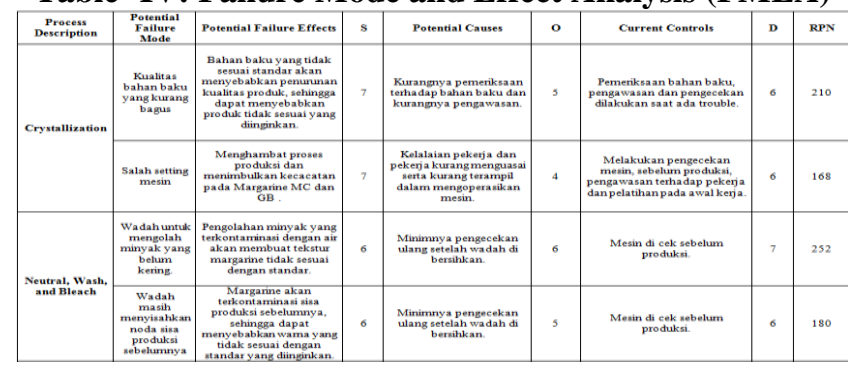

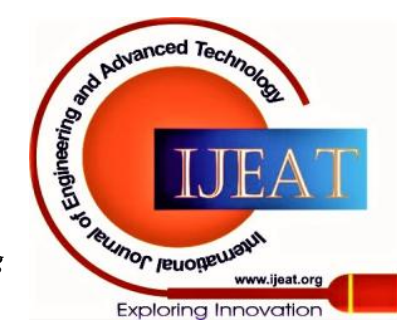




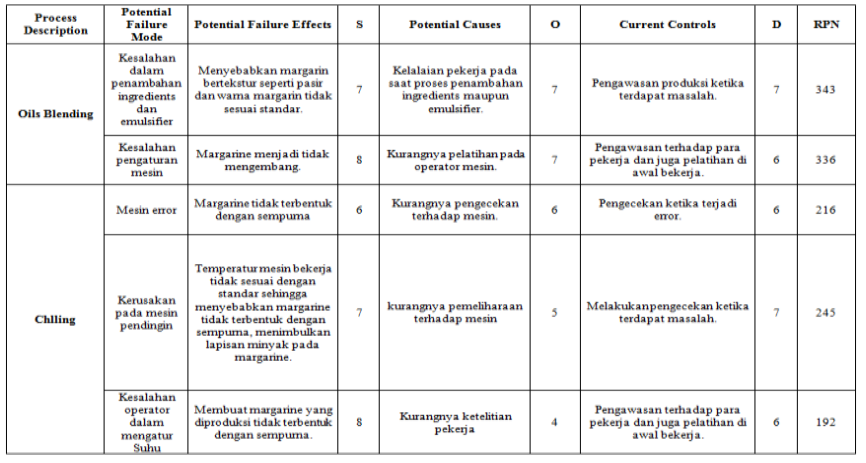

Source: PT. XY Z (2018)

Based on the data and calculations of the FMEA analysis above, it can be seen that the most significant potential defects occur during the Oils Blending process, where there are errors in adding ingredients and emulsifiers, with a total RPN (Risk Priority Number) of 343. This error can hamper the production process and result in disability in margarine production, where the margarine texture will be sandy.

\section{Improve}

In this stage, researchers provide recommendations to companies to offer actions to improvement using the RPN recapitulation table. It can be concluded that the right solution recommended by researchers for the company based on the causes is to provide detailed instructions as well as for preparations for the use of machines installed around the machine, both crystallization, oils blending, and chilling machines. Besides, regular briefings and periodic training are applied to workers to increase workers 'knowledge in assisting the production process, as well as tightening supervision in order to increase workers' accuracy and discipline so that problems do not occur in the production process.

\section{E. Control}

The last step is Control. The focus in this stage is to control and supervise the actions recommended by researchers. The company needs to inform and add insight and knowledge and actions needed by workers in the production process. In this study, the actions recommended by researchers to be carried out by PT. XYZ is installing instructions around the machine, training workers, improving supervision, and checking the machine regularly before starting the production process

\section{CONCLUSION}

\section{A. Conclusion}

After doing research in the production process, data processing, and also analysis of production data of PT. XYZ Chapter 4, the following conclusions can be obtained:

1. Based on the calculation of Defect Per Million Opportunity (DPMO) on the production process of Margarine MC and Margarine GB PT. XYZ, it is known that the company currently has a DPMO value of 22,677 ( margarine MC) and 23,273 (margarine GB), and sigma levels of 3.5 (margarine MC) and 3.49 (margarine GB), which based on the sigma level can be it is known that PT. XYZ is included in one of the industry standards in Indonesia. With a condition where the company has a target for the July 2015 to December 2017 period, as explained in

to grow and become a leader in the production of margarine International, PT. XYZ needs to make improvements in product quality so that companies can reduce the number of defects in margarine production and can reach the sigma level in international standards, namely sigma levels above 4 .

2. The results of the analysis of the Pareto diagram show that the largest types of disability are found in the types of sandy margarine, followed by oily margarine and finally the type of color-changing margarine, with a percentage of disability of $48.3 \%, 27.2 \%$ and $24.5 \%$ for Margarine MC, while the percentage of disability is $46.7 \%, 27 \%$, and $26.3 \%$ for Margarine GB. From the results of the causal diagram (fishbone diagram) shows that there are five factors that cause the occurrence of defective product problems that exist in the company PT. XYZ, which are man, method, materials, machine, and environment, where the main contributing factors are errors in entering ingredients and emulsifiers caused by worker's negligence, as well as workers who are less skilled or lack understanding of the standards in adding ingredients and emulsifiers in the production process based on the highest RPN value of 343.

3 . The results of the improve phase are the researchers proposed several corrective actions that can be done based on the recapitulation of RPN, where the highest RPN value is in oils blending process. Based on the results of interviews with resource persons, the company does not yet have a detailed strategy to overcome the problems that occur, the corrective action that can be done by the company is to implement the $5 \mathrm{~S}$ system by carrying out the Signboard Strategy, where the company makes an indication or explanation of the place, names of supporting materials, and the amount of supporting materials that must be added at the time of margarine production.

\section{B. Suggestion}

Based on the analysis and research conducted on the production process of margarine MC and margarine GB at PT. XYZ, efforts to increase and improve the quality of production can be made by reducing the factors that cause defects (defects). To achieve this, some suggestions that researchers can propose for PT. XYZ is as follows:

1. Researchers see several deficiencies that must be corrected in the production process that is not in accordance with the standards set by the company so as to produce a considerable amount of disability, where the standards set by the company are below 5\%. Companies need to implement the Six Sigma method DMAIC regularly so that it can help identify existing problems, correct errors, reduce the level of product defects, and improve the quality of the company's products.

2. By seeing the highest RPN value in the oils blending process caused by the negligence of workers who do not understand the details of the standard addition of ingredients and emulsifiers at the time of production, the company should provide training to workers regularly, appointing workers who have the competence to become supervisors, making guidelines or an explanation of the use of supporting materials and their amount, giving punishment if the worker makes a mistake, and cultivating a disciplined attitude to the worker.

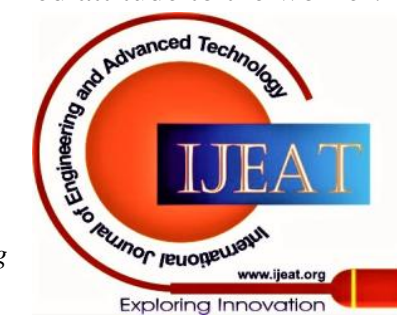


3. Companies should improve regulations relating to human resources to improve the quality of human resources and create value for the company in the form of increased profits caused by the reduced number of defective products. These things are suggestions for improvement recommended by researchers.

\section{REFERENCES}

1. H. Prastiyo and F. Ekoanindiy o, "Quality Control of Green Tea Products Using a Six Sigma Approach,” Ind. Eng. Study Progr., pp. 37-48, 2014.

\section{AUTHORS PROFILE}

Beatrix Oscar was born in Jakarta on August 30, 1996. Researchers completed their undergraduate education at Bina Nusantara University in Management in 2018

Billy Marten was born in Jakarta on August 23, 1995. Researchers completed their undergraduate education at Bina Nusantara University in Management in 2018.

Jenifer was born in Pontianak October 14, 1995. Researchers completing p Education S1 at Bina Nusantara University dal am in Management in 2018. 